\title{
Protein quality control in the endoplasmic reticulum
} Paul-Albert Koenig ${ }^{1}$ and Hidde L. Ploegh ${ }^{2}$

\author{
Addresses: ${ }^{1}$ Klinikum rechts der Isar, Technische Universität München, Institut für Klinische Chemie und Pathobiochemie, Ismaninger Straße 22, \\ 81675 München, Germany; ${ }^{2}$ Whitehead Institute for Biomedical Research, 9 Cambridge Center, Cambridge, 02142 MA, USA \\ * Corresponding author: Paul-Albert Koenig (koenig@lrz.tu-muenchen.de) \\ Fl000Prime Reports 2014, 6:49 (doi:10.12703/P6-49) \\ All FI000Prime Reports articles are distributed under the terms of the Creative Commons Attribution-Non Commercial License \\ (http://creativecommons.org/licenses/by-nc/3.0/legalcode), which permits non-commercial use, distribution, and reproduction in any medium, \\ provided the original work is properly cited. \\ The electronic version of this article is the complete one and can be found at: http://fl 000.com/prime/reports/b/6/49
}

\begin{abstract}
The topological barriers defined by biological membranes are not impermeable: from small solutes to intact proteins, specialized transport and translocation mechanisms adjust to the cell's needs. Here, we review the removal of unwanted proteins from the endoplasmic reticulum (ER) and emphasize the need to extend observations from tissue culture models and simple eukaryotes to studies in whole animals. The variation in protein production and composition that characterizes different cell types and tissues requires tailor-made solutions to exert proper control over both protein synthesis and breakdown. The ER is an organelle essential to achieve and maintain such homeostasis.
\end{abstract}

\section{Introduction}

Ever since its discovery as the site where secretory and membrane proteins start the journey to their final destination, the ER has attracted the attention of cell biologists and biochemists alike. Studded with ribosomes, the ER requires complex machinery to ensure proper docking of ribosomes, translocation of nascent polypeptide chains, and a suite of enzymes responsible for the introduction of the necessary co- and posttranslational modifications. Nascent protein chains must fold as they roll off the ribosome, both in the cytosol and for new arrivals in the lumen of the ER. Given the enormous diversity of amino acid sequences and the protein folds they specify, a diverse set of chaperones and accessory proteins support these efforts. However, mistakes are unavoidable, and the resulting misfits must be removed to avoid the futile engagement of chaperones better deployed elsewhere or to prevent the assembly of defective protein complexes. Many of the individual steps that together comprise protein quality control in the ER have been expertly (and frequently) reviewed [1-4]. Here, we provide a more integrated view and also discuss what I consider to be the next frontier: in vivo models based on our current in vitro models of how cells control the quality of proteins that enter the ER.

\section{Failure is an option}

In a typical eukaryotic cell, polypeptide chain elongation proceeds at a rate of 4 to 10 amino acids per second. Misacylation of transfer RNAs (tRNAs) results in the incorporation of the "wrong" amino acid, and even properly acylated tRNAs may misread their appropriate codon, with a similarly disastrous outcome. Inappropriate termination yields partial products, the stability of which is usually compromised. These types of mistakes apply equally to proteins made in the cytosol and to proteins destined for entry into the ER. These are not the only types of mishaps that can befall a nascent chain: a failure to engage the necessary co-factors that participate in giving a protein its final shape may propel an otherwise error-free nascent chain onto a non-productive folding pathway, from which escape may not be possible. The rate at which misfolded proteins arise is, therefore, carefully matched with the degradative capacity of the cell, as is evident from the relative abundance of the cytosolic proteasomes, the main protease complex responsible for ATP-dependent proteolysis [5].

The chemical environment in which protein folding occurs and where mistakes in protein structure must be diagnosed and dealt with is very different for the cytosol 
and for the ER. The lumen of the ER is a calcium-rich environment, whereas the cytosol is not: consequently, calcium-binding chaperones, such as calnexin and calreticulin participate in folding reactions in the ER. Many proteins that function in extracellular space are stabilized by disulfide bonds, the introduction of which occurs in the oxidizing environment of the ER lumen. Not surprisingly, disulfide bonds in cytosolic proteins are exceedingly rare.

The error rate in protein synthesis remains a controversial issue. Depending on the methodology used, defective ribosomal products may amount to a sizable fraction of newly synthesized material or represent only a small percentage of the primary translation product. Without taking sides in this somewhat contentious debate $[6,7]$, we wish to point out that the number of mistakes probably, by far, exceed the error rate in DNA replication. The many sophisticated mechanisms available to repair DNA damage ensure fidelity of transmission of genetic information, but errors in protein synthesis are usually dealt with by complete destruction of the faulty product.

\section{Proteolysis requires compartmentalization}

Protein breakdown serves a number of important functions. Complete hydrolysis of peptide bonds yields free amino acids for re-use as building blocks in protein synthesis. Proteolysis likewise serves to remove proteins no longer wanted or no longer functional because of the damage they sustained, either in the course of translation or upon completion of their useful lifespan. Protease activity must be compartmentalized to avoid uncontrolled attack on otherwise perfectly functional proteins. Moreover, nascent chains that have yet to assume their final folded structure are more susceptible to proteolysis than their complete and fully folded counterparts, one more reason for compartmentalization. In the case of cytosolic proteolysis, the bulk of protein degradation is performed at the hands of the ubiquitin-proteasome system [5]. The architecture of the 26S proteasome is such that access to the chamber where peptide bond hydrolysis occurs is tightly regulated, requiring ubiquitylation and the concerted action of AAA-ATPases that are part of the proteasomal cap complex to gain entry. Proteolysis in the topological equivalent of extracellular space is confined mostly to the endolysosomal system. Nonetheless, the chaperone-dependent import of cytosolic proteins destined for lysosomal degradation has been reported [8]. Likewise, the autophagy pathways sequester not only damaged organelles, such as mitochondria, but also soluble cytoplasmic constituents for delivery to the lysosomal compartment by a process of fusion and dissolution of internal membranes [9]. The ER presents a special case, as-with the exception of mitochondria-it is the only intracellular membrane-delimited compartment highly active in protein folding. Although the ER was originally believed to be a possible site of the proteolytic removal of misfolded glycoproteins [10], the prevailing view now centers on the physical removal of such substrates from the ER, followed by the delivery to the cytosol for proteasomal degradation [1-4].

\section{How to recognize a misfolded protein}

Regardless of whether the nascent chain folds in the cytosol or in the lumen of the ER, how the cell distinguishes a terminally misfolded state from a conformation with remaining options for corrective action is not clear. For obvious reasons, analysis of misfolded proteins precludes the use of the standard highly resolving methods, such as X-ray crystallography or nuclear magnetic resonance and instead relies on rather crude parameters, such as differential susceptibility to proteases, differences in aggregation state, the occlusion or display of antigenic determinants unique to the folded protein or its misfolded counterpart, or even a reduction in protein half-life as an inferred trait characteristic of a misfolded protein. For ER-lumenal proteins, the calnexin/calreticulin cycle employs an ER-resident glucosidase and (uridine 5'-diphospho-glucose-4-epimerase) [UDP]-glucose glycoprotein glucosyltransferase. The latter preferentially re-glucosylates proteins that conform to a molten globule state, leading to a prolonged interaction with calnexin/calreticulin, assisted by oxidoreductases, such as ERp57 to enable additional attempts at reaching a fully native fold [11]. For proteins that span the membrane, defects or possible points of recognition as misfolded can arise in each of the compartments with which they interact: the cytoplasmic aspect, as is the case for the $\Delta \mathrm{F} 508$ mutation in the cystic fibrosis transmembrane conductance regulator (CFTR) chloride conductance regulator, in the transmembrane segment(s) (for example, by failing to associate with appropriate partner subunits, as is the case for isolated subunits of the T-cell receptor for antigens, and in the luminal domains). Yos9p (yeast) and OS9 (mammalian cells) are lectin-like molecules that also participate in the recognition of substrates to be targeted for degradation [1-4].

\section{The unfolded protein response}

The unfolded protein response (UPR) is a stereotypical set of transcriptional events that follow imposition of acute ER stress [12]. Exposure of cells to stressors, such as tunicamycin, a drug that blocks GlcNAc-1-phosphotransferase, the first enzyme in the synthesis of the lipid-linked $\mathrm{N}$-linked glycan precursor, is a potent inducer of the UPR. Often overlooked is the fact that such treatment not only abolishes N-linked glycosylation, held responsible for the accumulation of proteins that misfold because of the 
elimination of glycans at their usual positions but also affects the level of the isoprenoid alcohol, dolichol, that may affect membrane structure and function. Given the abundance of calcium in the ER and the important role of calnexin/calreticulin in glycoprotein folding, perturbation of calcium homeostasis, as produced by the calcium pump inhibitor thapsigargin, would be predicted to adversely affect the folding of numerous glycoproteins and hence the induction of the UPR. Finally, preventing the formation of disulfide bonds by the exposure of cells to the reducing agent dithiothreitol (DTT) would be predicted to have similar effects and indeed induces the UPR. Transcriptional control of the UPR is well understood and involves the kinase/RNAse Ire1, the transcription factor precursor ATF6, and the kinase proline-rich receptor-like protein kinase (PERK1; for review, see [12]), all of which-directly or indirectly-cause induction and accumulation of proteins held capable of matching the folding and degradative capacity of the ER with the amount of misfolded protein accumulated. The kinds of physiological stressors that would similarly cause induction of the UPR remain to be identified, and there are relatively few examples of a protein deliberately designed to misfold inducing a robust UPR. The action of Ire1 induces the formation of XBP1s, the unconventionally spliced form of the transcription factor XBP1. Equally important is the contribution of the Ire1-dependent decay of particular messenger RNAs (mRNAs) and not just the de novo induction of transcription of key UPR targets, to ER homeostasis. Strong inducers of XBP1s are polyclonal B cell activators that propel virgin $B$ cells to become immunoglobulin-secreting cells [13]. Of note, the appearance of XBP1s precedes the onset of the massively increased rates of immunoglobulin secretion that characterize this transition [14], and thus this response is anticipatory rather than reactive, and might as well be an example of developmental regulation rather than damage control. Regardless of the distinctions between cause and consequence, many of the proteins implicated in the quality control of glycoproteins in the ER are upregulated when a UPR is induced, but it is by no means certain that their function is dedicated solely to protein quality control. Conversely, ablation of these quality control components may induce a UPR even in the absence of conventional UPR inducers such as tunicamycin, thapsigargin, or DTT.

\section{Dislocation}

Much of what we know about the quality control in the ER relies on the use of proteins that are misfolded because of mutations in their coding sequence. In yeast, a mutant version of carboxypeptidase $\mathrm{Y}$, (CPY), has been a popular workhorse. The pioneering work of Wolf and colleagues [15] and Sommer and Jentsch [16] called attention to a pathway, counterintuitive at first, that invoked the extraction of a misfolded protein from the ER, its translocation across the ER membrane-a key step now commonly referred to as dislocation or retrotranslocation-followed by proteasomal proteolysis. Hampton and Rine [17] have provided a detailed picture of the behavior of 3-hydroxy-3methylglutaryl-coenzyme A (HMG-CoA) reductase, the analysis of which led to the discovery of Hrd1-Hrd3 in yeast. The removal of membrane proteins from the ER poses yet another conundrum: if a polypeptide is extracted with its hydrophobic transmembrane segment(s) intact for transfer to the proteasome, how are these membraneanchoring segments shielded from aqueous solvent? The channel via which dislocation occurs remains a topic of interest, and perhaps more than one solution evolved to deal with the delivery of proteins from the ER to the cytosol, as discussed below.

\section{Model substrates and cell lines}

Biochemical analysis of dislocation and associated events in mammalian cells has relied extensively on a few model substrates, considered to be misfolded: the cystic fibrosisassociated mutant version of the CFTR $(\Delta \mathrm{F} 508)$, variants of $\alpha 1$-antitrypsin, unpaired T-cell receptor subunits, variants of the asialoglycoprotein receptor, or the enzyme tumor necrosis factor- $\alpha$-converting enzyme (TACE). Certain herpesvirus-encoded proteins such as the human cytomegalovirus (HCMV)-encoded US2 and US11 proteins apparently target properly folded class I major histocompatibility complex (MHC) products by exploiting the pathways that otherwise target misfolded proteins [1-4]. Although many of these studies exploit permanently established cell lines that express the degradation substrate(s) of interest, introduction of candidate substrates by transient transfection is commonly used as well. Based on a limited number of substrates, usually expressed and analyzed in easily manipulated cell lines in tissue culture, broad generalizations have come to dominate the field. Figures 1 and 2 provide a simplified schematic of some of the components for which there is a consensus as to their involvement in ER quality control. The often intimate connections between mitochondria and the ER [18] immediately suggest the possibility that transfer of proteins at these points of contact is also a point of quality control. Important areas that warrant further investigation include identification of natural, endogenous substrates of the degradation pathway [19] and events in the nuclear envelope, contiguous with the ER: we know little about how the cell manages selective protein turnover in the inner nuclear membrane and at the nuclear pore and the outer nuclear membrane.

\section{The machinery}

As far as degradation of ER-resident misfits is concerned, we can distinguish three broad classes of events: (a) recognition and engagement of degradation substrates; 
Figure I. Overall scheme of a typical endoplasmic reticulum (ER) quality control pathway

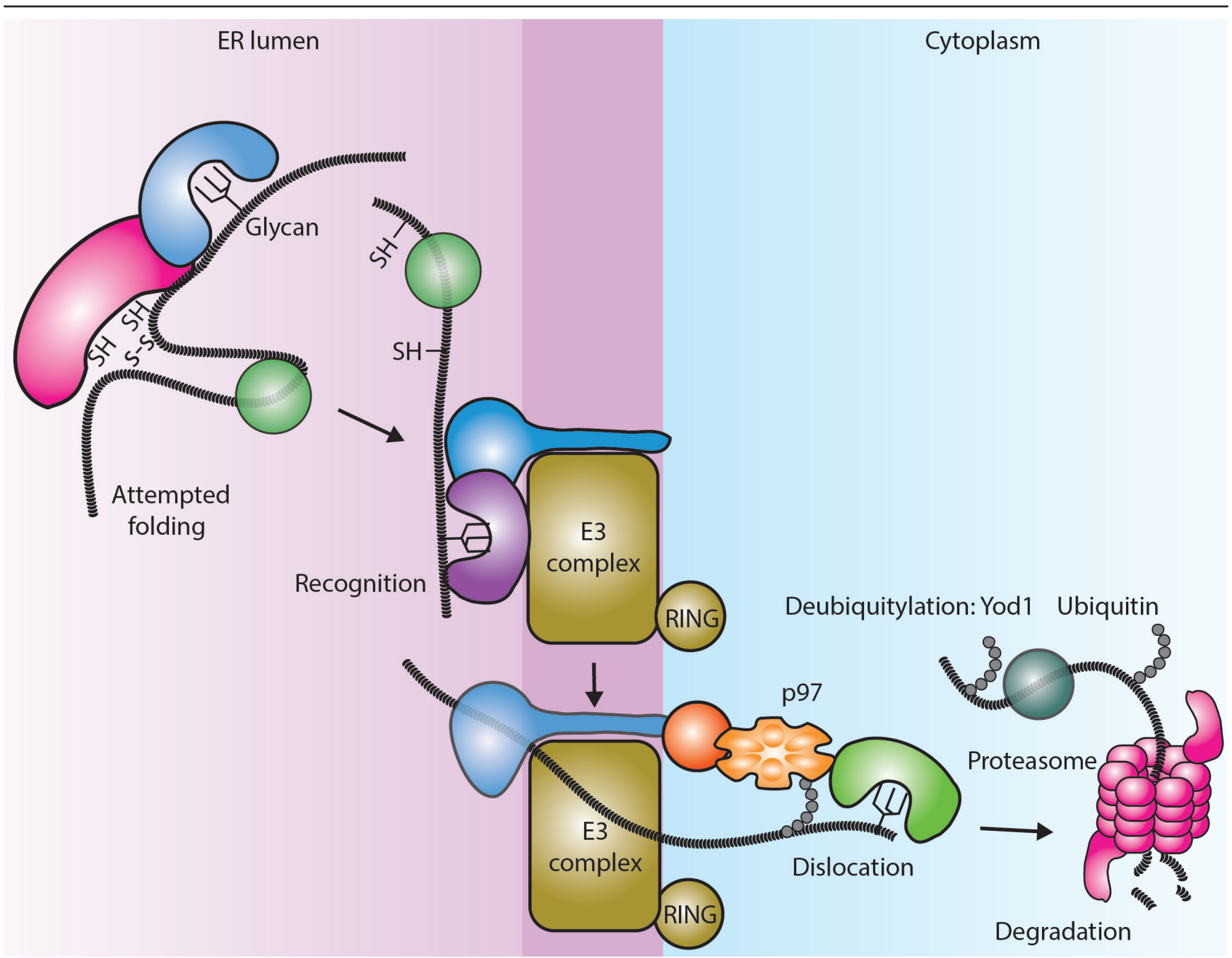

Recognition of misfolded secretory proteins involves molecules that sense glycosylation and redox status. Transfer to an ER-resident ubiquitin ligase complex may require additional proteins. The mechanical force for dislocation can be provided by the AAA-ATPase p97. Cytosolically disposed glycans are removed coincident with or prior to transfer to the proteasome. Ubiquitin is removed and recycled prior to highly processive proteolysis by the $26 \mathrm{~S}$ proteasome.

(b) translocation across the ER membrane, involving the components that constitute the dislocon; and (c) ubiquitylation/deubiquitylation reactions; ubiquitylation reactions may generate the necessary "handles" for exertion of physical force (for example, by the AAA-ATPase p97) to effectuate extraction of the substrate from the ER. Ubiquitylation/deubiquitylation reactions may obviously require different types of ubiquitin linkages and would necessitate involvement of distinct ubiquitin-conjugating enzymes and deubiquitylating enzymes. Typical approaches that implicate the involvement of key components involve co-immunoprecipitation experiments, often in conjunction with mass spectrometry, to validate protein-protein interactions [20], and gene disruptions (Table 1) or short hairpin RNA-based knockdowns of specific components or in genome-wide screens. The composition of this machinery is depicted in Figures 1 and 2. Key sensors of misfolded proteins include oxidoreductases and carbohydrate-binding proteins, not all of which have been identified. There is an important role for an ER-resident mannosidase, ER degradation-enhancing alpha-mannosidase-like protein 1 (EDEM-1). In addition, members of the heat shock protein (HSP) family, such as Bip and Gp96, together with their J-domain containing co-chaperones, have been implicated in substrate recognition. The levels of these sensors may themselves be controlled by the very same mechanisms that deal with misfolded proteins and thus may enable "tuning" of ER quality control [21]. In the absence of massive quantities of misfolded proteins, the need for sensors and other components of the quality control machinery is 
Figure 2. Schematic of the dislocation-Ub ligase complex centered on Hrd I-SelIL

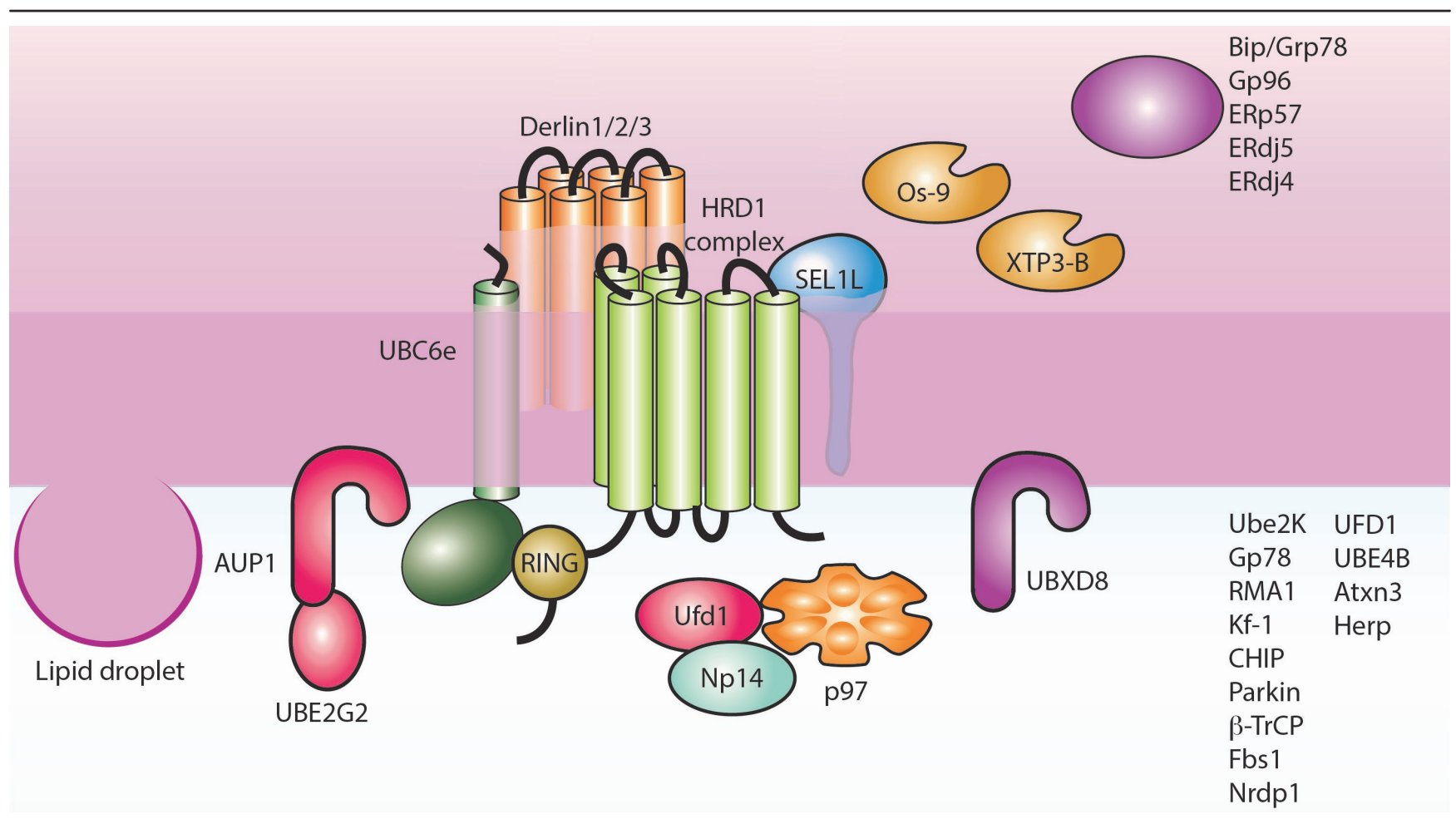

The HrdI-Sel IL complex interacts with the tail-anchored Ubc6e (Ube2jl), which serves as the E2-conjugating enzyme for HrdI-Sel IL. Members of the heat shock protein (HSP) family, such as Bip/Grp78 and their co-chaperones (J-domain-containing proteins) together with the lectin-like molecule Os-9 and XTP3-B deliver misfolded substrates to the HrdI-Sel IL complex for dislocation via the HrdI-Sel IL-Derlin complex, followed by the extraction via P97 and its associated co-factors UfdI and Npl4. The mechanistic details of how other proteins participate in dislocation, such as UbxD8 and the lipid droplet-associated AUPI protein, together with Ube2G2, a cytosolic E2-conjugating enzyme, remain to be worked out. The list of proteins on the right have all been implicated in endoplasmic reticulum (ER) quality control, as summarized in Table I.

reduced, and a rapid switch must be possible should such accumulation occur. Transfer to the channels via which dislocation occurs may involve the channel proteins themselves, and proteins such as OS9, capable of recognizing not only misfolded glycosylated proteins but also proteins devoid of glycans. The identity of the channel itself remains ill defined, and it is likely that in fact multiple such channels exist. Strong biochemical evidence implicates Hrd1-Hrd3 (yeast) and Hrd1-Sel1L (mammals) as possible protein-conducting channels. Although Sec61 was initially considered a plausible candidate to facilitate translocation in reverse [22] export from the ER (instead of import into the ER), further experimental support for this notion has yet to emerge. The Derlins, discovered as proteins essential for dislocation, were also considered conduits to allow proteins to exit from the ER, and their proposed structural similarity to rhomboid intra-membranous proteases $[23,24]$ is consistent with such a role. Moreover, for the HCMVencoded immune evasion US2, an association with signal peptide peptidase was observed [25], suggesting possible analogies between intramembranous signal peptide recognition and handling transmembrane segments of proteins destined for extraction from the ER.

\section{Lipids}

Since lipids are not template-encoded and cannot be manipulated easily by genetic modifications, the participation of lipids in protein dislocation is an appealing proposition, proposed in a model that employs the genesis of lipid droplets [26]. Although this model has not met with experimental support in yeast [27], the metabolism of HMG-CoA reductase suggests the involvement of lipid droplets in ensuring its ubiquitylation [28]. This reaction requires AUP1, implicated in glycoprotein degradation in the HCMV immune evasion model [29].

Knockout models in mice are becoming increasingly manageable in terms of ease of production and tissuespecific control over the actual deletion events, relying on site-specific inducible recombinases, such as inducible Cre in combination with LoxP sites. Although deletion of the 
Table I. Mouse models affected in components of the endoplasmic reticulum quality control pathway

I. Recognition of substrate and 2. Possible connections to the dislocon
Bip/Grp78: embryonic lethal (a). Tissue-specific knockouts in adipocytes, prostate epithelial cells, or Purkinje cells produce severe cellular defects in the affected tissues [30-46].

Gp96: embryonic lethal. Tissue- or cell type-specific knockouts show severe phenotypes. Because gp96 is a co-factor essential for Toll-like receptor (TLR) expression, TLR-driven responses are compromised in gp96-deficent macrophages [47-64].

ERp57: embryonic lethal. ERp57-deficient B cells are largely normal [65-68].

ERdj5: ER stress in salivary gland [69]

ERdj4: perinatal death; constitutive induction of the unfolded protein response (UPR) in various tissues [70]

SelI L: embryonic lethal. Induced deletion of floxed allele post-natally causes constitutive UPR, and death within 3 weeks, possibly because of nutrient malabsorption [7|-74].

Derlin-I: embryonic lethal [75]

Derlin-2: perinatal lethality, constitutive UPR, mild cartilage defect [76]

Derlin-3: viable. Levels of Derlin-I and -2 are decreased in pancreas [75].

Herp: increased levels of HrdI. In various tissues, glucose tolerance is impaired [75].

3. Ubiquitylation and deubiquitylation

Ube2K: viable. Levels of caspase 12 are reduced in cortical neurons [77].

HrdI: embryonic lethal, aberrant apoptosis. Hemizygous deletion causes multiple effects in models of acute liver toxicity (less fibrosis) [78-8I].

Gp78: stabilization of CD82 and Insig-I in gp78-deficient mouse embryo fibroblasts [82,83]

RMAI: Inducible transgenic overexpression causes weight loss and muscle wasting [84,85].

Kf-I: also called "hicky mouse". Anxiety-like behavior is increased [86].

CHIP: normal development. But perinatal lethality is approximately 25\% [87-91].

Parkin: viable and fertile but with motor and cognitive defects [92-98]

$\beta$-TrCP: If exon I is deleted, the mouse model is viable, fertile, and superficially normal but with defects in retinal development. If exon 5 is deleted, fertility is reduced [99-105].

Fbs I: superficially normal but with age-related hearing loss [106,107]

Nrdp I: Transgenic overexpression produces less pro-inflammatory cytokines [108-II0].

SmurfI: superficially normal with enhanced osteoblast activity [III]

UFDI: superficially normal [II2]

UBE4B: embryonic lethal. Overexpression causes neural degeneration [1/3,114].

Atxn3: viable and phenotypically normal with increased tissue ubiquitin levels [115,116]

Yod-I: Inducible expression of a dominant-negative version (catalytically inactive) contributes to enhanced cross presentation [1 I7].

Calreticulin, calnexin, and UDP-glucose glycoprotein glycosyltransferase (UGGT): calreticulin: heart, brain, and body wall defects; calnexin: early post-natal death and motor disorders; UGGT: embryonic lethal [II8-120]

The approximate position of the listed components may be found in Figures I and 2.

genes for some of the ER quality control causes embryonic lethality (probably in accord with expectations), several prominent players can be eliminated without system-wide defects in protein management.

Below, we provide a brief list of the currently available (conditional) mouse null mutants or transgenic overexpressors and some of the phenotypes recorded for them, more fully described in the references cited. What this survey demonstrates is the essential nature of many of the components identified in the ER quality control pathway and the remarkable degree of tissue-specific aberrations in cellular physiology when using cell type- or tissue-specific knockouts. If we take into account the large variations in protein composition across different tissues and cell types and take note of the fact that, for many ubiquitously expressed genes, knockout phenotypes can be remarkably cell type- and tissue-specific, this should not come as a surprise. The remarkably coherent picture that has emerged from the study of a relatively limited number 
of substrates, cell lines, and experimental tissue culture models will surely require adjustment in view of the continued investment in mouse models. Recent developments, such as cas9/CRISPR genome-editing methods will undoubtedly lead to a remarkable expansion and acceleration in this exciting field.

\section{Abbreviations}

CFTR, cystic fibrosis transmembrane conductance regulator; DTT, dithiothreitol; ER, endoplasmic reticulum; HCMV, human cytomegalovirus; 3-hydroxy-3methylglutaryl-coenzyme A, HMG-CoA; tRNA, transfer RNA; UPR, unfolded protein response; XBP1, X-box binding protein 1.

\section{Disclosures}

The authors declare that they have no disclosures.

\section{References}

I. Smith MH, Ploegh HL, Weissman JS: Road to ruin: targeting proteins for degradation in the endoplasmic reticulum. Science 20II, 334:1086-90.

2. Hebert DN, Bernasconi R, Molinari M: ERAD substrates: which way out? Semin Cell Dev Biol 2010, 21:526-32.

3. Olzmann JA, Kopito RR, Christianson JC: The mammalian endoplasmic reticulum-associated degradation system. Cold Spring Harb Perspect Biol 2013, 5.

4. Amm I, Sommer T, Wolf DH: Protein quality control and elimination of protein waste: the role of the ubiquitin-proteasome system. Biochim Biophys Acta 2014, 1843:182-96.

5. Sommer T, Wolf DH: The ubiquitin-proteasome-system. Biochim Biophys Acta 2014, 1843:1.

6. Schubert U, Antón LC, Gibbs J, Norbury CC, Yewdell JW, Bennink JR: Rapid degradation of a large fraction of newly synthesized proteins by proteasomes. Nature 2000, 404:770-4.

7. Rock KL, Farfán-Arribas DJ, Colbert JD, Goldberg AL: Re-examining class-I presentation and the DRiP hypothesis. Trends Immunol 20|4, 35: |44-52.

8. Salvador N, Aguado C, Horst M, Knecht E: Import of a cytosolic protein into lysosomes by chaperone-mediated autophagy depends on its folding state. J Biol Chem 2000, 275:27447-56.

\section{FlOOOPrime}

\section{RECOMMENDED}

9. Ge L, Baskaran S, Schekman R, Hurley JH: The protein-vesicle network of autophagy. Curr Opin Cell Biol 2014, 29C:I8-24.

10. Lippincott-Schwartz J, Bonifacino JS, Yuan LC, Klausner RD: Degradation from the endoplasmic reticulum: disposing of newly synthesized proteins. Cell 1988, 54:209-20.

II. Hebert DN, Molinari M: Flagging and docking: dual roles for $\mathbf{N}$ glycans in protein quality control and cellular proteostasis. Trends Biochem Sci 2012, 37:404-10.

12. Walter $P$, Ron $D$ : The unfolded protein response: from stress pathway to homeostatic regulation. Science 20II, 334:108I-6.

13. Reimold AM, Iwakoshi NN, Manis J, Vallabhajosyula P, SzomolanyiTsuda E, Gravallese EM, Friend D, Grusby M], Alt F, Glimcher LH: Plasma cell differentiation requires the transcription factor XBP-I. Nature 200I, 4I 2:300-7.

\section{FlOOOPrime}

I4. van Anken E, Romijn EP, Maggioni C, Mezghrani A, Sitia R, Braakman I, Heck Albert J R: Sequential waves of functionally related proteins are expressed when B cells prepare for antibody secretion. Immunity 2003, I8:243-53.

\section{FlOOOPRime
RECOMMENDED}

15. Knop M, Finger A, Braun T, Hellmuth K, Wolf DH: Der I, a novel protein specifically required for endoplasmic reticulum degradation in yeast. EMBO J 1996, 15:753-63.

16. Sommer T, Jentsch S: A protein translocation defect linked to ubiquitin conjugation at the endoplasmic reticulum. Nature 1993, 365:176-9.

17. Hampton RY, Rine J: Regulated degradation of HMG-CoA reductase, an integral membrane protein of the endoplasmic reticulum, in yeast. J Cell Biol 1994, I 25:299-3 I2.

18. Michel $\mathrm{AH}$, Kornmann B: The ERMES complex and ERmitochondria connections. Biochem Soc Trans 2012, 40:445-50.

\section{FlOOOPrime} RECOMMENDED

19. Tyler RE, Pearce Margaret M P, Shaler TA, Olzmann JA, Greenblatt EJ, Kopito RR: Unassembled CDI47 is an endogenous endoplasmic reticulum-associated degradation substrate. Mol Biol Cell 2012, 23:4668-78.

\section{FlOOOPrime}

\section{RECOMMENDED}

20. Christianson JC, Olzmann JA, Shaler TA, Sowa ME, Bennett EJ, Richter CM, Tyler RE, Greenblatt EJ, Harper JW, Kopito RR: Defining human ERAD networks through an integrative mapping strategy. Nat Cell Biol 2012, I4:93-I05.

\section{FlOOOPrime}

21. Bernasconi R, Galli C, Kokame K, Molinari M: Autoadaptive ERassociated degradation defines a preemptive unfolded protein response pathway. Mol Cell 2013, 52:783-93.

22. Wiertz EJ, Tortorella D, Bogyo M, Yu J, Mothes W, Jones TR, Rapoport TA, Ploegh HL: Sec6I-mediated transfer of a membrane protein from the endoplasmic reticulum to the proteasome for destruction. Nature 1996, 384:432-8.

23. Greenblatt EJ, Olzmann JA, Kopito RR: Derlin-I is a rhomboid pseudoprotease required for the dislocation of mutant $\alpha-I$ antitrypsin from the endoplasmic reticulum. Nat Struct Mol Biol 20II, I8: I 147-52.

\section{FlOOOPrime
RECOMMENDED}

24. Greenblatt EJ, Olzmann JA, Kopito RR: Making the cut: intramembrane cleavage by a rhomboid protease promotes ERAD. Nat Struct Mol Biol 2012, 19:979-8I.

\section{FIOOOPRime}

25. Loureiro J, Lilley BN, Spooner E, Noriega V, Tortorella D, Ploegh HL: Signal peptide peptidase is required for dislocation from the endoplasmic reticulum. Nature 2006, 441:894-7.

\section{FlOOOPrime
RECOMMENDED}

26. Ploegh HL: A lipid-based model for the creation of an escape hatch from the endoplasmic reticulum. Nature 2007, 448:435-8.

27. Olzmann JA, Richter CM, Kopito RR: Spatial regulation of UBXD8 and p97/VCP controls ATGL-mediated lipid droplet turnover. Proc Natl Acad Sci USA 2013, I I 0:1345-50.

28. Jo Y, Hartman IZ, DeBose-Boyd RA: Ancient ubiquitous protein-I mediates sterol-induced ubiquitination of 3-hydroxy-3-methylglutaryl CoA reductase in lipid droplet-associated endoplasmic reticulum membranes. Mol Biol Cell 20I3, 24:169-83. 
29. Klemm EJ, Spooner E, Ploegh HL: Dual role of ancient ubiquitous protein I (AUPI) in lipid droplet accumulation and endoplasmic reticulum (ER) protein quality control. J Biol Chem 20II, 286:37602-I4.

30. Mimura N, Hamada H, Kashio M, Jin H, Toyama Y, Kimura K, lida M, Goto S, Saisho H, Toshimori K, Koseki H, Aoe T: Aberrant quality control in the endoplasmic reticulum impairs the biosynthesis of pulmonary surfactant in mice expressing mutant BiP. Cell Death Differ 2007, 14:1475-85.

31. Dobashi T, Tanabe S, Jin H, Mimura N, Yamamoto T, Nishino T, Aoe $\mathrm{T}$ : BiP, an endoplasmic reticulum chaperone, modulates the development of morphine antinociceptive tolerance. J Cell Mol Med 2010, 14:2816-26.

32. Kimura K, Jin H, Ogawa M, Aoe T: Dysfunction of the ER chaperone BiP accelerates the renal tubular injury. Biochem Biophys Res Commun 2008, 366: 1048-53.

33. Mimura N, Yuasa S, Soma M, Jin H, Kimura K, Goto S, Koseki H, Aoe $T$ : Altered quality control in the endoplasmic reticulum causes cortical dysplasia in knock-in mice expressing a mutant BiP. Mol Cell Biol 2008, 28:293-30I.

34. Dwyer ND, Manning DK, Moran JL, Mudbhary R, Fleming MS, Favero CB, Vock VM, O'Leary Dennis D M, Walsh CA, Beier DR: A forward genetic screen with a thalamocortical axon reporter mouse yields novel neurodevelopment mutants and a distinct emx2 mutant phenotype. Neural Dev 20II, 6:3.

35. Favero CB, Henshaw RN, Grimsley-Myers CM, Shrestha A, Beier DR, Dwyer ND: Mutation of the BiP/GRP78 gene causes axon outgrowth and fasciculation defects in the thalamocortical connections of the mammalian forebrain. J Comp Neurol 2013, 521:677-96.

36. Luo S, Mao C, Lee B, Lee AS: GRP78/BiP is required for cell proliferation and protecting the inner cell mass from apoptosis during early mouse embryonic development. Mol Cell Biol 2006, 26:5688-97.

\section{FlOOOPrime}

37. Zhu G, Ye R, Jung DY, Barron E, Friedline RH, Benoit VM, Hinton DR, Kim JK, Lee AS: GRP78 plays an essential role in adipogenesis and postnatal growth in mice. FASEB J 20I3, 27:955-64.

38. Fu Y, Wey S, Wang M, Ye R, Liao C, Roy-Burman P, Lee AS: Pten null prostate tumorigenesis and AKT activation are blocked by targeted knockout of ER chaperone GRP78/BiP in prostate epithelium. Proc Natl Acad Sci USA 2008, 105:19444-9.

39. Ye R, Jung DY, Jun JY, Li J, Luo S, Ko HJ, Kim JK, Lee AS: Grp78 heterozygosity promotes adaptive unfolded protein response and attenuates diet-induced obesity and insulin resistance. Diabetes 2010, 59:6-16.

40. Wang M, Ye R, Barron E, Baumeister P, Mao C, Luo S, Fu Y, Luo B, Dubeau L, Hinton DR, Lee AS: Essential role of the unfolded protein response regulator GRP78/BiP in protection from neuronal apoptosis. Cell Death Differ 2010, 17:488-98.

4I. Ye R, Mareninova OA, Barron E, Wang M, Hinton DR, Pandol SJ, Lee AS: Grp78 heterozygosity regulates chaperone balance in exocrine pancreas with differential response to ceruleininduced acute pancreatitis. Am J Pathol 2010, 177:2827-36.

42. Wey S, Luo B, Tseng C, Ni M, Zhou H, Fu Y, Bhojwani D, Carroll WL, Lee AS: Inducible knockout of GRP78/BiP in the hematopoietic system suppresses Pten-null leukemogenesis and AKT oncogenic signaling. Blood 2012, I 19:8I7-25.

43. Yoo S, You S, Yoon H, Kim D, Kim H, Lee K, Ahn JH, Hwang D, Lee AS, Kim K, Park Y, Cho C, Kim W: A novel pathogenic role of the ER chaperone GRP78/BiP in rheumatoid arthritis. J Exp Med 20I2, 209:87|-86.

\section{FlOOOPrime} RECOMMENDED

44. Dong D, Stapleton C, Luo B, Xiong S, Ye W, Zhang Y, Jhaveri N, Zhu G, Ye R, Liu Z, Bruhn KW, Craft N, Groshen S, Hofman FM, Lee AS: A critical role for GRP78/BiP in the tumor microenvironment for neovascularization during tumor growth and metastasis. Cancer Res 201 I, 71:2848-57.

45. Ji C, Kaplowitz N, Lau MY, Kao E, Petrovic LM, Lee AS: Liverspecific loss of glucose-regulated protein 78 perturbs the unfolded protein response and exacerbates a spectrum of liver diseases in mice. Hepatology 20II, 54:229-39.

46. Wey S, Luo B, Lee AS: Acute inducible ablation of GRP78 reveals its role in hematopoietic stem cell survival, lymphogenesis and regulation of stress signaling. PLOS ONE 20I2, 7:e39047.

47. Yang Y, Liu B, Dai J, Srivastava PK, Zammit DJ, Lefrançois L, Li Z: Heat shock protein gp96 is a master chaperone for toll-like receptors and is important in the innate function of macrophages. Immunity 2007, 26:2I5-26.

\section{FlOOOPrime} RECOMMENDED

48. Liu B, Li Z: Endoplasmic reticulum HSP90b I (gp96, grp94) optimizes B-cell function via chaperoning integrin and TLR but not immunoglobulin. Blood 2008, I | 2: |223-30.

49. Staron M, Yang Y, Liu B, Li J, Shen Y, Zúñiga-Pflücker JC, Aguila HL, Goldschneider I, Li Z: gp96, an endoplasmic reticulum master chaperone for integrins and Toll-like receptors, selectively regulates early T and B lymphopoiesis. Blood 2010, I I 5:2380-90.

50. Staron M, Wu S, Hong F, Stojanovic A, Du X, Bona R, Liu B, Li Z: Heatshock protein gp96/grp94 is an essential chaperone for the platelet glycoprotein Ib-IX-V complex. Blood 20 I I, I I7:7 | 36-44.

5I. Audouard C, Le Masson F, Charry C, Li Z, Christians ES: Oocytetargeted deletion reveals that hsp90bl is needed for the completion of first mitosis in mouse zygotes. PLOS ONE 20I I, 6: el7109.

52. Audouard C, Christians E: Hsp903I knockout targeted to male germline: a mouse model for globozoospermia. Fertil Steril 20II, 95: |475-7.el-4.

53. Barton ER, Park S, James JK, Makarewich CA, Philippou A, Eletto D, Lei H, Brisson B, Ostrovsky O, Li Z, Argon Y: Deletion of muscle GRP94 impairs both muscle and body growth by inhibiting local IGF production. FASEB J 2012, 26:3691-702.

54. Liu B, Staron M, Li Z: Murine but not human basophil undergoes cell-specific proteolysis of a major endoplasmic reticulum chaperone. PLOS ONE 2012, 7:e39442.

55. Liu B, Staron M, Hong F, Wu BX, Sun S, Morales C, Crosson CE, Tomlinson S, Kim I, Wu D, Li Z: Essential roles of grp94 in gut homeostasis via chaperoning canonical Wnt pathway. Proc Natl Acad Sci USA 2013, I l 0:6877-82.

56. Hua $Y$, White-Gilbertson S, Kellner J, Rachidi S, Usmani SZ, Chiosis G, Depinho R, Li Z, Liu B: Molecular chaperone gp96 is a novel therapeutic target of multiple myeloma. Clin Cancer Res 2013, | 9:6242-5|.

57. Zhang Y, Helke KL, Coelho SG, Valencia JC, Hearing VJ, Sun S, Liu B, Li Z: Essential role of the molecular chaperone gp96 in regulating melanogenesis. Pigment Cell Melanoma Res 20I4, 27:82-9.

58. Morales $C$, Rachidi S, Hong F, Sun S, Ouyang X, Wallace C, Zhang Y, Garret-Mayer E, Wu J, Liu B, Li Z: Immune chaperone gp96 drives the contributions of macrophages to inflammatory colon tumorigenesis. Cancer Res 2014, 74:446-59.

59. Wanderling S, Simen BB, Ostrovsky O, Ahmed NT, Vogen SM, Gidalevitz T, Argon Y: GRP94 is essential for mesoderm induction and muscle development because it regulates insulin-like growth factor secretion. Mol Biol Cell 2007, 18:3764-75.

60. Ostrovsky O, Ahmed NT, Argon Y: The chaperone activity of GRP94 toward insulin-like growth factor II is necessary for the stress response to serum deprivation. Mol Biol Cell 2009, 20:1855-64.

61. Mao C, Wang M, Luo B, Wey S, Dong D, Wesselschmidt $R$ Rawlings S, Lee AS: Targeted mutation of the mouse Grp94 gene disrupts development and perturbs endoplasmic reticulum stress signaling. PLOS ONE 2010, 5: el 0852.

62. Luo B, Lam BS, Lee SH, Wey S, Zhou H, Wang M, Chen S, Adams GB, Lee AS: The endoplasmic reticulum chaperone protein GRP94 is required for maintaining hematopoietic stem cell 
interactions with the adult bone marrow niche. PLOS ONE 20II, 6:e20364

63. Chen W, Tseng C, Pfaffenbach K, Kanel G, Luo B, Stiles BL, Lee AS: Liver-specific knockout of GRP94 in mice disrupts cell adhesion, activates liver progenitor cells, and accelerates liver tumorigenesis. Hepatology 2014, 59:947-57.

64. Garbi N, Tanaka S, Momburg F, Hämmerling GJ: Impaired assembly of the major histocompatibility complex class I peptideloading complex in mice deficient in the oxidoreductase ERp57. Nat Immunol 2006, 7:93-102.

\section{FlOOOPrime
RECOMMENDED}

65. Coe H, Jung J, Groenendyk J, Prins D, Michalak M: ERp57 modulates STAT3 signaling from the lumen of the endoplasmic reticulum. J Biol Chem 2010, 285:6725-38.

66. Prins D, Groenendyk J, Touret N, Michalak M: Modulation of STIMI and capacitative $\mathrm{Ca2}+$ entry by the endoplasmic reticulum luminal oxidoreductase ERp57. EMBO Rep 201I, I 2: | | 82-8.

67. Wang L, Wu Y, Zhou J, Ahmad SS, Mutus B, Garbi N, Hämmerling G, Liu J, Essex DW: Platelet-derived ERp57 mediates platelet incorporation into a growing thrombus by regulation of the

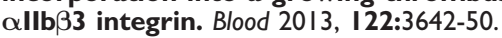

68. Nemere I, Garbi N, Hämmerling GJ, Khanal RC: Intestinal cell calcium uptake and the targeted knockout of the I,25D3MARRS (membrane-associated, rapid response steroid-binding) receptor/PDIA3/Erp57. J Biol Chem 2010, 285:3 1859-66.

69. Hosoda A, Tokuda M, Akai R, Kohno K, Iwawaki T: Positive contribution of ERdj5/JPDI to endoplasmic reticulum protein quality control in the salivary gland. Biochem J 2010, 425: I I7-25.

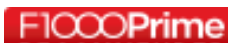

RECOMMENDED

70. Fritz JM, Dong M, Apsley KS, Martin EP, Na C, Sitaraman S, Weaver TE: Deficiency of the BiP cochaperone ERdj4 causes constitutive endoplasmic reticulum stress and metabolic defects. Mol Biol Cell 2014, 25:43I-40.

\section{FlOOOPrime \\ RECOMMENDED}

7I. Francisco AB, Singh R, Li S, Vani AK, Yang L, Munroe RJ, Diaferia G, Cardano M, Biunno I, Qi L, Schimenti JC, Long Q: Deficiency of suppressor enhancer Lin 12 I like (SELIL) in mice leads to systemic endoplasmic reticulum stress and embryonic lethality. J Biol Chem 2010, 285: I3694-703.

\section{FIOOOPrime}

72. Li S, Francisco AB, Munroe RJ, Schimenti JC, Long Q: SELIL deficiency impairs growth and differentiation of pancreatic epithelial cells. BMC Dev Biol 2010, 10:19.

73. Cardano M, Diaferia GR, Cattaneo M, Dessì SS, Long Q, Conti L, Deblasio P, Cattaneo E, Biunno I: mSEL-IL (Suppressor/enhancer Lin I 2-like) protein levels influence murine neural stem cell selfrenewal and lineage commitment. J Biol Chem 20 I I, 286: I8708-I9.

74. Sun S, Shi $G$, Han $X$, Francisco AB, Ji $Y$, Mendonça $N$, Liu $X$, Locasale JW, Simpson KW, Duhamel GE, Kersten S, Yates JR, Long Q, Qi L: SellL is indispensable for mammalian endoplasmic reticulum-associated degradation, endoplasmic reticulum homeostasis, and survival. Proc Natl Acad Sci USA 20 I4, I I I:E582-9I.

\section{FlOOOPrime}

RECOMMENDED

75. Eura Y, Yanamoto H, Arai Y, Okuda T, Miyata T, Kokame K: Derlin- I deficiency is embryonic lethal, Derlin-3 deficiency appears normal, and Herp deficiency is intolerant to glucose load and ischemia in mice. PLOS ONE 2012, 7:e34298.

\section{FlOOOPrime \\ RECOMMENDED}

76. Dougan SK, Hu CA, Paquet M, Greenblatt MB, Kim J, Lilley BN, Watson N, Ploegh HL: Derlin-2-deficient mice reveal an essential role for protein dislocation in chondrocytes. Mol Cell Biol 20 I I, 3 I: | | 45-59.

77. Song S, Lee H, Kam T, Tai ML, Lee J, Noh J, Shim SM, Seo SJ, Kong Y, Nakagawa T, Chung C, Choi D, Oubrahim H, Jung Y: E2-25K/Hip-2 regulates caspase- I 2 in ER stress-mediated Abeta neurotoxicity. J Cell Biol 2008, I 82:675-84.

\section{FlOOOPrime
RECOMMENDED}

78. Amano T, Yamasaki S, Yagishita N, Tsuchimochi K, Shin H, Kawahara K, Aratani S, Fujita H, Zhang L, Ikeda R, Fujii R, Miura N, Komiya S, Nishioka K, Maruyama I, Fukamizu A, Nakajima T: Synoviolin/HrdI, an E3 ubiquitin ligase, as a novel pathogenic factor for arthropathy. Genes Dev 2003, I 7:2436-49.

\section{FlOOOPrime
RECOMMENDED}

79. Yagishita $\mathrm{N}$, Ohneda $\mathrm{K}$, Amano $\mathrm{T}$, Yamasaki S, Sugiura $\mathrm{A}$, Tsuchimochi K, Shin H, Kawahara K, Ohneda O, Ohta T, Tanaka S, Yamamoto M, Maruyama I, Nishioka K, Fukamizu A, Nakajima T: Essential role of synoviolin in embryogenesis. J Biol Chem 2005, 280:7909-16.

80. Yamasaki S, Yagishita N, Sasaki T, Nakazawa M, Kato Y, Yamadera T, Bae E, Toriyama S, Ikeda R, Zhang L, Fujitani K, Yoo E, Tsuchimochi K, Ohta T, Araya N, Fujita H, Aratani S, Eguchi K, Komiya S, Maruyama I, Higashi N, Sato M, Senoo H, Ochi T, Yokoyama S, Amano T, Kim J, Gay S, Fukamizu A, Nishioka K, et al.: Cytoplasmic destruction of p53 by the endoplasmic reticulum-resident ubiquitin ligase 'Synoviolin'. EMBO J 2007, 26: I I3-22.

\section{FlOOOPrime}

\section{RECOMMENDED}

8I. Hasegawa D, Fujii R, Yagishita N, Matsumoto N, Aratani S, Izumi T, Azakami K, Nakazawa M, Fujita H, Sato T, Araya N, Koike J, Tadokoro M, Suzuki N, Nagata K, Senoo H, Friedman SL, Nishioka K, Yamano $\mathrm{Y}$, Itoh F, Nakajima T: E3 ubiquitin ligase synoviolin is involved in liver fibrogenesis. PLOS ONE 2010, 5:e I3590.

82. Tsai YC, Leichner GS, Pearce Margaret M P, Wilson GL, Wojcikiewicz Richard J H, Roitelman J, Weissman AM: Differential regulation of HMG-CoA reductase and Insig-I by enzymes of the ubiquitin-proteasome system. Mol Biol Cell 2012, 23:4484-94.

83. Liu T, Tang J, Li P, Shen Y, Li J, Miao H, Li B, Song B: Ablation of gp78 in liver improves hyperlipidemia and insulin resistance by inhibiting SREBP to decrease lipid biosynthesis. Cell Metab 2012, 16:213-25.

84. Delaunay A, Bromberg KD, Hayashi Y, Mirabella M, Burch D, Kirkwood B, Serra C, Malicdan MC, Mizisin AP, Morosetti R, Broccolini A, Guo LT, Jones SN, Lira SA, Puri PL, Shelton GD, Ronai Z: The ER-bound RING finger protein 5 (RNF5/RMAI) causes degenerative myopathy in transgenic mice and is deregulated in inclusion body myositis. PLOS ONE 2008, 3:e I609.

85. Kuang E, Okumura Cheryl Y M, Sheffy-Levin S, Varsano T, Shu VC, Qi ], Niesman IR, Yang H, López-Otín C, Yang WY, Reed JC, Broday L, Nizet V, Ronai ZA: Regulation of ATG4B stability by RNF5 limits basal levels of autophagy and influences susceptibility to bacterial infection. PLoS Genet 2012, 8: el 003007.

86. Tsujimura A, Matsuki M, Takao K, Yamanishi K, Miyakawa T, Hashimoto-Gotoh T: Mice lacking the kf-I gene exhibit increased anxiety- but not despair-like behavior. Front Behav Neurosci 2008, 2:4

\section{FlOOOPrime
RECOMMENDED}

87. Dai Q, Zhang C, Wu Y, McDonough H, Whaley RA, Godfrey V, Li H, Madamanchi N, Xu W, Neckers L, Cyr D, Patterson C: CHIP activates HSFI and confers protection against apoptosis and cellular stress. EMBO J 2003, 22:5446-58.

88. Zhang C, Xu Z, He X, Michael LH, Patterson C: CHIP, a cochaperonel ubiquitin ligase that regulates protein quality control, is required for maximal cardioprotection after myocardial infarction in mice. Am J Physiol Heart Circ Physiol 2005, 288:H2836-42.

89. McLaughlin B, Buendia MA, Saborido TP, Palubinsky AM, Stankowski JN, Stanwood GD: Haploinsufficiency of the E3 ubiquitin ligase 
C-terminus of heat shock cognate $\mathbf{7 0}$ interacting protein (CHIP) produces specific behavioral impairments. PLOS ONE 2012, 7:e36340.

90. Shi C, Schisler JC, Rubel CE, Tan S, Song B, McDonough H, Xu L, Portbury AL, Mao C, True C, Wang R, Wang Q, Sun S, Seminara SB, Patterson $C, X u$ Y: Ataxia and hypogonadism caused by the loss of ubiquitin ligase activity of the $\mathbf{U}$ box protein CHIP. Hum Mol Genet 2014, 23:1013-24.

91. Sahara N, Murayama M, Mizoroki T, Urushitani M, Imai Y, Takahashi R, Murata S, Tanaka K, Takashima A: In vivo evidence of CHIP upregulation attenuating tau aggregation. J Neurochem 2005, 94: 1254-63.

92. Goldberg MS, Fleming SM, Palacino |l, Cepeda C, Lam HA, Bhatnagar A, Meloni EG, Wu N, Ackerson LC, Klapstein GJ, Gajendiran M, Roth BL, Chesselet M, Maidment NT, Levine MS, Shen J: Parkin-deficient mice exhibit nigrostriatal deficits but not loss of dopaminergic neurons. J Biol Chem 2003, 278:43628-35.

\section{FlOOOPrime}

93. Itier J, Ibanez P, Mena MA, Abbas N, Cohen-Salmon C, Bohme GA, Laville M, Pratt J, Corti O, Pradier L, Ret G, Joubert C, Periquet M, Araujo F, Negroni J, Casarejos MJ, Canals S, Solano R, Serrano A, Gallego E, Sanchez M, Denefle P, Benavides J, Tremp G, Rooney TA, Brice A, Garcia de Yebenes Justo: Parkin gene inactivation alters behaviour and dopamine neurotransmission in the mouse. Hum Mol Genet 2003, I 2:2277-9I.

94. Coelln R, von Thomas B, Savitt JM, Lim KL, Sasaki M, Hess EJ, Dawson VL, Dawson TM: Loss of locus coeruleus neurons and reduced startle in parkin null mice. Proc Natl Acad Sci U S A 2004, 101:10744-9.

95. Perez FA, Palmiter RD: Parkin-deficient mice are not a robust model of parkinsonism. Proc Natl Acad Sci USA 2005, I02:2 I74-9.

96. Stichel CC, Zhu X, Bader V, Linnartz B, Schmidt S, Lübbert H: Monoand double-mutant mouse models of Parkinson's disease display severe mitochondrial damage. Hum Mol Genet 2007, 16:2377-93.

97. Kitao $Y$, Imai $Y$, Ozawa K, Kataoka A, Ikeda T, Soda M, Nakimawa K, Kiyama H, Stern DM, Hori O, Wakamatsu K, Ito S, Itohara S, Takahashi R, Ogawa S: Pael receptor induces death of dopaminergic neurons in the substantia nigra via endoplasmic reticulum stress and dopamine toxicity, which is enhanced under condition of parkin inactivation. Hum Mol Genet 2007, 16:50-60.

98. Roth JA, Singleton S, Feng J, Garrick M, Paradkar PN: Parkin regulates metal transport via proteasomal degradation of the IB isoforms of divalent metal transporter I. J Neurochem 2010, I 1 3:454-64.

99. Nakayama K, Hatakeyama S, Maruyama S, Kikuchi A, Onoé K, Good RA, Nakayama Kl: Impaired degradation of inhibitory subunit of NF-kappa B (I kappa B) and beta-catenin as a result of targeted disruption of the beta-TrCPI gene. Proc Natl Acad Sci U S A 2003, 100:8752-7.

100. Baguma-Nibasheka M, Kablar B: Abnormal retinal development in the Btrc null mouse. Dev Dyn 2009, 238:2680-7.

I0I. Ohsaki K, Oishi K, Kozono Y, Nakayama K, Nakayama KI, Ishida N: The role of $\{$ beta\}-TrCPI and \{beta\}-TrCP2 in circadian rhythm generation by mediating degradation of clock protein PER2. J Biochem 2008, 144:609-18.

102. Guardavaccaro D, Kudo Y, Boulaire J, Barchi M, Busino L, Donzelli M, Margottin-Goguet F, Jackson PK, Yamasaki L, Pagano M: Control of meiotic and mitotic progression by the $F$ box protein betaTrcpI in vivo. Dev Cell 2003, 4:799-8I2.

103. Kudo Y, Guardavaccaro D, Santamaria PG, Koyama-Nasu R, Latres E, Bronson R, Yamasaki L, Pagano M: Role of F-box protein betaTrcp I in mammary gland development and tumorigenesis. Mol Cell Biol 2004, 24:8184-94.

104. Kanarek N, Horwitz E, Mayan I, Leshets M, Cojocaru G, Davis M, Tsuberi B, Pikarsky E, Pagano M, Ben-Neriah Y: Spermatogenesis rescue in a mouse deficient for the ubiquitin ligase SCF $\{$ beta\}TrCP by single substrate depletion. Genes Dev 2010, 24:470-7.
105. Belaïdouni N, Peuchmaur M, Perret C, Florentin A, Benarous R, Besnard-Guérin C: Overexpression of human beta TrCPI deleted of its $F$ box induces tumorigenesis in transgenic mice. Oncogene 2005, 24:227I-6.

106. Nelson RF, Glenn KA, Zhang Y, Wen H, Knutson T, Gouvion CM, Robinson BK, Zhou Z, Yang B, Smith Richard J H, Paulson HL: Selective cochlear degeneration in mice lacking the F-box protein, Fbx2, a glycoprotein-specific ubiquitin ligase subunit. J Neurosci 2007, 27:5163-7|.

\section{FIOOOPrime
RECOMMENDED}

107. Atkin G, Hunt J, Minakawa E, Sharkey L, Tipper N, Tennant W, Paulson HL: F-box only protein 2 (Fbxo2) Regulates Amyloid Precursor Levels and Processing. J Biol Chem 2014, .

108. Wang C, Chen T, Zhang J, Yang M, Li N, Xu X, Cao X: The E3 ubiquitin ligase NrdpI 'preferentially' promotes TLRmediated production of type I interferon. Nat Immunol 2009, 10:744-52.

109. Zhang Y, Zeng Y, Wang M, Tian C, Ma X, Chen H, Fang Q, Jia L, Du J, $\mathrm{Li} \mathrm{H}$ : Cardiac-specific overexpression of E3 ligase NrdpI increases ischemia and reperfusion-induced cardiac injury. Basic Res Cardiol 20I I, 106:37I-83.

I10. Zhang Y, Kang Y, Tian C, Zeng Y, Jia L, Ma X, Du J, Li H: Overexpression of $\mathrm{Nrdpl}$ in the heart exacerbates doxorubicin-induced cardiac dysfunction in mice. PLOS ONE 20 I I, 6:e2I I 04.

III. Yamashita M, Ying S, Zhang G, Li C, Cheng SY, Deng C, Zhang YE: Ubiquitin ligase SmurfI controls osteoblast activity and bone homeostasis by targeting MEKK2 for degradation. Cell 2005, |21:101-13.

\section{FlOOOPrime \\ RECOMMENDED}

112. Lindsay EA, Botta A, Jurecic V, Carattini-Rivera S, Cheah YC, Rosenblatt HM, Bradley A, Baldini A: Congenital heart disease in mice deficient for the DiGeorge syndrome region. Nature 1999, 401:379-83.

II3. Kaneko-Oshikawa C, Nakagawa T, Yamada M, Yoshikawa $H$ Matsumoto M, Yada M, Hatakeyama S, Nakayama K, Nakayama Kl: Mammalian E4 is required for cardiac development and maintenance of the nervous system. Mol Cell Biol 2005, 25: 10953-64.

FlOOOPrime RECOMMENDED

I I4. Susaki E, Kaneko-Oshikawa C, Miyata K, Tabata M, Yamada T, Oike Y, Katagiri $\mathrm{H}$, Nakayama KI: Increased E4 activity in mice leads to ubiquitin-containing aggregates and degeneration of hypothalamic neurons resulting in obesity. J Biol Chem 2010, 285: 15538-47.

\section{FlOOOPrime}

I 15. Schmitt I, Linden M, Khazneh H, Evert BO, Breuer P, Klockgether T, Wuellner U: Inactivation of the mouse Atxn3 (ataxin-3) gene increases protein ubiquitination. Biochem Biophys Res Commun 2007, 362:734-9.

II6. Switonski PM, Fiszer A, Kazmierska K, Kurpisz M, Krzyzosiak WJ, Figiel M: Mouse ataxin-3 functional knock-out model. Neuromolecular Med 20I I, 13:54-65.

1 17. Sehrawat S, Koenig P, Kirak O, Schlieker C, Fankhauser M, Ploegh HL: A catalytically inactive mutant of the deubiquitylase YOD-I enhances antigen cross-presentation. Blood 2013, I 21 : | 145-56.

118. Rauch F, Prud'homme J, Arabian A, Dedhar S, St-Arnaud R: Heart, brain, and body wall defects in mice lacking calreticulin. Exp Cell Res 2000, 256:105-II.

119. Denzel A, Molinari M, Trigueros C, Martin JE, Velmurgan S, Brown S, Stamp G, Owen MJ: Early postnatal death and motor disorders in mice congenitally deficient in calnexin expression. Mol Cell Biol 2002, 22:7398-404.

I20. Molinari M, Galli C, Vanoni O, Arnold SM, Kaufman RJ: Persistent glycoprotein misfolding activates the glucosidase II/UGTIdriven calnexin cycle to delay aggregation and loss of folding competence. Mol Cell 2005, 20:503-12. 